\title{
Intra-abdominal granulomas caused by Clostridium tertium in an American Fuzzy Lop rabbit
}

\author{
Mirella Lauria D'Elia' (iD) Alice Barroso Santos' ${ }^{1}$ Beatriz Novaes Telles Ribeiro' $^{1}$ \\ Renato Cesar Sacchetto Torres ${ }^{1}$ Renato de Lima Santos ${ }^{1}$ (D) \\ Rodrigo Otávio Silveira Silva1 ${ }^{1}$ Anelise Carvalho Nepomuceno1 ${ }^{1}$ (D)
}

${ }^{1}$ Escola de Veterinária, Universidade Federal de Minas Gerais (UFMG), Antônio Carlos Avenue, 6627, 31270-901, Belo Horizonte, MG, Brasil. E-mail: anelise-imagem@ufmg.br. "Corresponding author.

ABSTRACT: A 6-year-old Fuzzy Lop rabbit was referred to a veterinary hospital with a complaint of lameness. In addition to a vertebral subluxation, two radiopaque and well-defined structures were revealed by radiographic evaluation. Ultrasonographically, the masses were characterized as parenchymal structures with diffuse mineralization and formation of reverberation artifacts, suggesting presence of gas. These two structures were excised during a laparotomy and Clostridium tertium was isolated. To the best of our knowledge, this is the first report of $C$. tertium infection in a pet animal.

Key words: Clostridia, granuloma, diagnostic imaging.

\author{
Granulomas intra-abdominais causados por Clostridium tertium \\ em um coelho American Fuzzy Lop
}

RESUMO: Um coelho de seis anos de idade da raça Fuzzy Lop foi encaminhado a um hospital veterinário devido a uma queixa de claudicação. Além de uma subluxação vertebral, duas estruturas radiopacas e bem delimitadas foram identificadas pela avaliação radiográfica. Em um exame ultrassonográfico, as massas foram caracterizadas como formações parenquimatosas e heterogêneas, apresentando mineralização difusa e com formação de artefatos de reverberação, sugerindo a presença de gás. Estas duas estruturas foram extirpadas durante uma laparotomia e Clostridium tertium foi isolado. Este é o primeiro relato de infecção por C. tertium em um animal de estimação.

Palavras-chave: Clostridia, granuloma, diagnóstico por imagem.

Unconventional pet animal breeding has been increasing over recent years in Brazil and worldwide. According to IBGE (Brazilian Institute for Statistics and Geography), there are more than two million reptiles and small mammals kept as pets in Brazil (ABINPET, 2013). Despite the increasing numbers of rabbits raised as pets, studies on diseases that affect these animals under this condition are scarce, making it difficult to provide more efficacious clinical attention to these animals. Therefore, the goal of this report is to describe a case of intra-abdominal granulomas caused by Clostridium tertium in the abdominal cavity of a Fuzzy Lop rabbit.

A female 6-year-old Fuzzy Lop rabbit, weighting $2.6 \mathrm{~kg}$, was admitted at the Veterinary Hospital of Universidade Federal de Minas Gerais (UFMG) due to a complaint of lameness. The rabbit had a history of being hospitalized when she was two-years-old due to severe diarrhea and apathy. At that time, the rabbit was treated with antimicrobial and support therapy, but the cause of the disease was not identified. Radiographic evaluation of the lumbar vertebrae demonstrated a subluxation between the last thoracic and first lumbar vertebrae. There were also two well circumscribed round abdominal structures that were predominantly radiopaque, but had an irregular radiographic density. The larger one was approximately $3.5 \times 2.0 \mathrm{~cm}$, and it was located in the right epigastric region over the last three ribs in a ventral-dorsal projection. The other structure had a rounder shape measuring approximately $2.7 \times 2.6 \mathrm{~cm}$, with variable topography when the animal was repositioned for better exposure (still in dorsal decumbency), occupying the left lateral abdominal area superimposed to the first described structure or superimposed to the vertebral column at the thoracolumbar transition (Figure 1A and B).

The rabbit received anti-inflammatory treatment (meloxicam, $0.3 \mathrm{mg} / \mathrm{Kg}$ ) for 14 days, which 

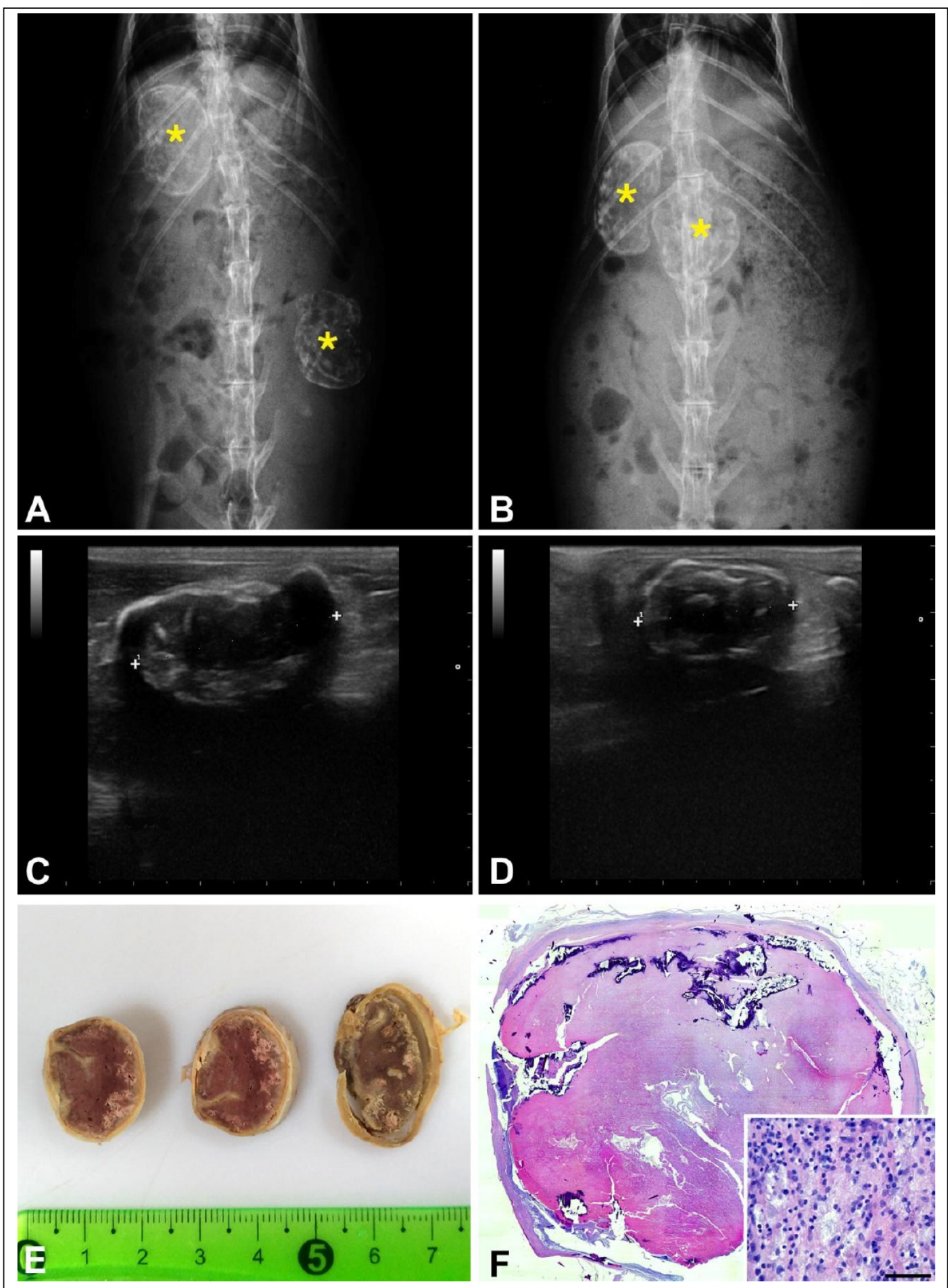

Figure 1 - Radiographic images of the vertebral column:(A) lateral-lateral and (B) ventral-dorsal, demonstrating predominantly radiopaque structures $\left(^{*}\right)$ in the abdominal cavity, one of which demonstrated mobility when the animal was re-positioned. Ultrasonographic images of the abdominal nodules: $(\mathrm{C})$ one located the right epigastric region and measuring $3.09 \mathrm{~cm}$ in length, and (D) the other in the mesogastric region and measuring approximately $2.33 \mathrm{~cm}$ in length. Both nodules had heterogeneous echotexture and a hyperecoic surface. (E) Cut surface of nodular lesions, the mobile nodule corresponding to the two fragments in the left and the nodule adjacent to the liver in on the right, predominantly red color intermixed with yellowish areas, with mineralization. (F) Submacroscopic appearance of the granuloma, with an extensive central area of necrosis and mineralization, and a lympho-histiocytic infiltrate at the periphery (inset); hematoxylin and eosin, Bar $=50 \mu \mathrm{m}$. 
reduced the clinical signs of lameness. Sixty days later, the rabbit returned to the hospital with worsened locomotor clinical signs, associated with apathy and weight loss (from 2.6 to $1.6 \mathrm{~kg}$ ). The animal was then subjected to ultrasonography for assessment of the abdominal nodular lesions. Ultrasonographically, the nodules were characterized as parenchymal structures with markedly heterogeneous echotexture. There was diffuse mineralization that was more concentrated at the periphery of the nodules with reverberation artifacts suggesting the presence of gas. Both lesions were well circumscribed with irregular margins. The larger lesion was attached to the liver and adjacent to the pylorus, whereas the smaller was located caudally to the left kidney, and it had evident mobility within the abdominal cavity (Figures 1C and D). Due to the presence of gas, an ultrasound guided biopsy was not performed.

Hematologic examination demonstrated decreased numbers of white cells $\left(4 \times 10^{-3} / \mathrm{mm}^{3}\right.$; reference values: $\left.5-12 \times 10^{-3} / \mathrm{mm}^{3}\right)$, neutrophilia $(63 \%$; reference values: $30-50 \%)$ and lymphopenia $(27 \%$; reference values: $30-60 \%$ ) compatible with a persistent infection. In rabbits, low white blood cell counts can beeported in association with chronic diseases and changes in the distribution of white cells can occur in response to infection with a relative neutrophilia and lymphopenia (VARGAS, 2014).

Based on imaging and laboratory results, an exploratory laparotomy was elected. A nodule was identified in the right epigastric region, which was slightly adhered to the liver. The other nodule was firm and tightly adhered to the omentum in the mesogastric region, which explains the previously observed mobility of this particular nodule. Excision of both nodules was performed and samples were collected for bacterial isolation (held at $4{ }^{\circ} \mathrm{C}$ ) and for histopathology (fixed by immersion in $10 \%$ bufferedformalin). During laparotomy, the uteruses appeared enlarged with multiple cysts bilaterally. Therefore, an ovariohysterectomy was performed and samples of the uterus were collected for histopathology.

Grossly, the nodules were encapsulated, oval, and firm. On cut surface, they were predominantly red intermixed with yellowish areas, with mineralization (Figure 1E). Histologic sections were stained with hematoxylin and eosin, and Gram staining. Histologically, both nodular lesions were characterized by extensive areas of necrosis in the center of the lesion with occasional heterophilic infiltrate and multifocal mineralization. At the periphery of the lesion there was a marked inflammatory infiltrate, predominantly histiocytic with numerous epithelioid cells (Figure 1F) and abundant fibrosis. There were multiple intra lesional bacterial colonies composed of Gram-positive bacilli. The uterine lesion was characterized by an invasive neoplastic epithelial proliferation in a tubulopapillary pattern that was diagnosed as a uterine carcinoma. No histologic changes were observed in the ovaries and uterine tubes.

The nodule submitted for bacterial analysis was incised with a sterilized scalpel. A swab was used to sample its content, which was then inoculated on two plates of agar Mueller-Hinton (Difco, USA) supplemented with $5 \%$ of desfibrinated sheep blood. One plate was incubated aerobically at $37^{\circ} \mathrm{C}$ for 48 hours, while the other plate was incubated in an anaerobic chamber at $37^{\circ} \mathrm{C}$ for 48 hours. No growth was visible on the plate cultured aerobically, whereas colonies of Gram-positive rods grew on the plate incubated anaerobically. These colonies were then submitted to mass spectrometry (MALDITOF, Brucker, USA) andidentified as C.tertium. The laboratory detection of $C$. tertium from the nodule corroborates the findings reported during the ultrasonography, which detected the presence of gas in the nodules, as well as the histopathological analysis that reported the presence of intralesional Gram-positive organisms.

The owner reported that after the surgery the animal recovered well and gained weight. Unfortunately, nine months after the procedure the rabbit was found dead. The postmortem analysis indicated gastric volvulus as the cause of death.

The literature on intra-abdominal granulomas in rabbits is scarce. Infectious and zoonotic agents such as Mycobacteriumtuberculosis and Encephalitozooncuniculi are responsible for the development of granulomas in rabbits, the first agent being related to the occurrence of granulomas in the lungs and the second one in the brain, kidney, liver, lens, and heart; although, other organs may be affected (JASSAL et al., 2011; VARGAS, 2014; RODRÍGUEZ-TOVAR et al., 2016). There are no previous reports of intra-abdominal granulomas in rabbits caused by bacteria of the genus Clostridium. The occurrence of other types of nodular lesions, such as abscesses, are commonly secondary to trauma, previous surgeries, bacteremia or local inflammation (OGLESBEE, 2011). Specifically in rabbits, case reports of abscess are often restricted to facial abscess associated with trauma or, more commonly, odontogenic (HOYLES et al., 2000; WARD et al., 2006; PAGLIARANI et al., 2014; BROWN et al., 2016; CAPELLO et al., 2016). Intra-abdominal 
abscess caused by Escherichia coli has been reported in a rabbit possibly as a result of a perforation of the colon (TSUKANE et al., 2004). In the present report, no predisposing factors or primary causes were identified. The only possible predisposing factor in this case was the diagnosis of two current diseases: the rabbit was in pain due its locomotor alteration and was diagnosed with a uterine carcinoma. These two diseases could have directly or indirectly impaired the immune system, favoring the occurrence of this opportunistic infection (VANDERHOFSTADT et al., 2010; OGLESBEE, 2011; VARGAS, 2014).

The agent isolated from the granuloma in this case is also quite interesting. C. tertium is an anaerobic bacterium that can be isolated from soil or from the gastrointestinal tract of animals and humans (VANDERHOFSTADT et al., 2010). Despite being part of the microbiota, C. tertium has been associated with bacteremia in humans, primarily in neutropenic patients (VALTONEN et al., 1990; LEEGAARD et al., 2005; VANDERHOFSTADT et al., 2010; SALVADOR et al., 2013). However, there are reports of $C$. tertium infection occurring in healthy human patients, suggesting that this bacterium may be more pathogenic than previously thought (LEW et al., 1990; RAY et al., 2003; TAPPE et al., 2005; STEENSMA et al., 2011; CHALHOUB et al., 2016; BARAKAT et al., 2018). It is noteworthy that, among these studies, there are no reports of granulomas caused by $C$. tertium in humans or other animals. Conversely, there are two reports of $C$. tertium causing an abscess in healthy individuals (LEW et al., 1990; BARAKAT et al., 2018). LEW et al. (1990) reported the involvement of $C$. tertium in a post-traumatic brain abscess, while BARAKAT et al. (2018) recently reported a liver abscess caused by this agent. The distinct morphologic presentation in this case, i.e. granuloma vs. abscess, is likely due to chronicity. In animals, $C$. tertium has been incriminated as a possible enteropathogen for calves (SILVEIRA et al., 2003), and it has been isolated from an abscess detected between the blubber and musculature of a striped dolphin (Stenellacoeruleoalba) (SEOL et al., 2006).

To the best of our knowledge, this is the first reported case of C.tertium infection in a pet animal. Although, C. tertium is recognized as a lowvirulence Gram-positive bacterium, this report clearly demonstrated that it is capable of inducing chronic infection in rabbits. Further studies should focus on genome comparative analysis of clinical versus environmental isolates in order to better explain the role of $C$. tertium as pathogens and also to clarify if there is any zoonotic potential.

\section{CONFLICT OF INTEREST STATEMENT}

The authors declare no conflict of interest.

\section{ACKNOWLEDGEMENTS}

This study was supported by Coordenação de Aperfeiçoamento de Pessoal de Nível Superior (CAPES), Conselho Nacional de Desenvolvimento Científico e Tecnológico $(\mathrm{CNPq})$, Fundação de Amparo à Pesquisa do Estado de Minas Gerais (FAPEMIG) and Pró Reitoria de Pesquisa / Universidade Federal de Minas Gerais (PRPq/UFMG)

\section{AUTHORS' CONTRIBUTIONS}

The authors contributed equally to the manuscript.

\section{REFERENCES}

ABINPET - Associação Brasileira da Indústria de Produtos para Animais de Estimação. Available from: $<$ http://abinpet.org. br/site/mercado/>. Accessed: Sept. 21, 2017.

BROWN T. et al. Ventralrhinotomy in a pet rabbit (Oryctolaguscuniculus) with an odontogenic abscess and subobstructive rhinitis. Can Vet J. 2016 Aug; 57(8):873-8.

CAPELLO V. Surgical treatment of facial abscesses and facial Surgery in Pet Rabbits. VetClin North Am ExotAnimPract. 2016 Sept.; 19(3):799-823.

CHALHOUB V. Septic shock due to Clostridium tertium in an immunocompetent patient following colitis without inflammatory bowel disease. Anaesth Crit Care Pain Med. 2016 Apr.; 35(2):167-8.

JASSALM. S. A modified scoring system to describe gross pathology in the rabbit model of tuberculosis. BMC Microbiology 2011, 11-49.

LEEGAARD T. M. Clostridium tertium: 3 case reports. Scand J Infect Dis. 2005; 37(3):230-2.

LEW J. F. Aerotolerant Clostridium tertium brain abscess following a lawn dart injury. J ClinMicrobiol. 1990 Sept.; 28(9): 2127-2129.

BARAKAT M. et al. Clostridium tertium: An Unusual Cause of Pyogenic Liver Abscess. ACG Case Rep J. 2018; 5: e30.

OGLESBEE, B. L. Blackwell's Five-Minute Veterinary Consult Small Mammals: Rabbit. 2. ed. Ohio: Wiley-Blackwell, 2011. 453p.

PAGLIARANI S. Facial abscess in a rabbit secondary to sewing-pin ingestion and cheek perforation. J Small AnimPract. 2014 Nov.; 55(11):597.

RAY P. et al. Clostridium tertium in Necrotizing Fasciitis and Gangrene. Emerg Infect Dis. 2003 Oct.; 9(10): 1347-1348.

RAY P. et al. Clostridium tertium in necrotizing fasciitis and gangrene. Emerg Infect Dis. 2003 Oct.; 9(10):1347-8. 
RODRÍGUEZ-TOVAR L. E. et al. Encephalitozooncuniculi: Grading the Histological Lesions in Brain, Kidney, and Liver during Primoinfection Outbreak in Rabbits. Journal of Pathogens, Volume 2016, Article ID 5768428, 9 pages. Available from: $<$ http:// dx.doi.org/10.1155/2016/5768428>. Accessed: Sept. 21, 2017.

SALVADORF. etal.Breakthrough bacteremiadueto Clostridium tertium in a patient with neutropenic fever, and identification by MALDI-TOF mass spectrometry. Int J Infect Dis. 2013 Nov;17(11):e1062-3.

SEOL B. Isolation of Clostridium tertium from a striped dolphin (Stenellacoeruleoalba) in the Adriatic Sea. J Wildl Dis. 2006 Jul.; 42(3):709-11.

STEENSMA E. A. Clostridium tertium isolated from a necrotizing soft tissue infection in a diabetic but otherwise nonimmunocompromised patient. J Am Col Certif Wound Spec. 2011 Sept. $17 ; 3(2): 42-4$.

TAPPE D. F et al. Clostridium tertiumsepticemia in a nonneutropenic patient. J Infect. 2005 Jan.; 50(1):76-80.
TSUKANE E. et al. Intraabdominalabcess in a rabbit. J AnimClin Med, 2004, 12 (4) 197-199.

VALTONEN M. A cluster of seven cases of Clostridium tertium septicemia in neutropenic patients. Eur J ClinMicrobiol Infect Dis. 1990 Jan.; 9(1):40-2.

VANDERHOFSTADT M. Clostridium tertium bacteremia: contamination or true pathogen? A report of two cases and a review of the literature. Int J Infect Dis. 2010 Sept.; 14 Supp13:e335-7.

VARGAS, M. Rabbit Basic Science. In: Textbook of Rabbit Medicine. 2. ed. British: Elsevier, 2014. Cap 1, p. 3-108.

Clinical Pathology. In: Textbook of Rabbit Medicine. 2. ed. British: Elsevier, 2014. Cap 2, p. 111-136.

WARD M. L. Diagnosis and management of a retrobulbar abscess of periapical origin in a domestic rabbit. VetClin North Am ExotAnimPract. 2006 Sept.; 9(3):657-65. 